\title{
Juvenile sea stars exposed to acidification decrease feeding and growth with no acclimation potential
}

\author{
Yasmin S. Appelhans ${ }^{1, * * *}$, Jörn Thomsen ${ }^{1, * * * *}$, Sebastian Opitz ${ }^{1,2}$, Christian Pansch $^{1,3}$, \\ Frank Melzner ${ }^{1}$, Martin Wahl ${ }^{1}$ \\ ${ }^{1}$ Helmholtz Centre for Ocean Research (GEOMAR), Marine Ecology, Düsternbrooker Weg 20, 24105 Kiel, Germany \\ ${ }^{2}$ Present address: Leibniz Institute for Science and Mathematics Education, Olshausenstraße 62, 24118 Kiel, Germany \\ ${ }^{3}$ Present address: Department of Biological and Environmental Sciences - Tjarno, University of Gothenburg, \\ 45296 Stromstad, Sweden
}

\begin{abstract}
Ocean acidification has the potential to affect growth and calcification of benthic marine invertebrates, particularly during their early life history. We exposed field-collected juveniles of Asterias rubens from Kiel Fjord (western Baltic Sea) to 3 seawater $\mathrm{CO}_{2}$ partial pressure $\left(\mathrm{pCO}_{2}\right)$ levels (ranging from around 650 to $\left.3500 \mu \mathrm{atm}\right)$ in a long-term (39 wk) and a short-term (6 wk) experiment. In both experiments, survival and calcification were not affected by elevated $\mathrm{pCO}_{2}$. However, feeding rates decreased strongly with increasing $\mathrm{pCO}_{2}$, while aerobic metabolism and $\mathrm{NH}_{4}{ }^{+}$excretion were not significantly affected by $\mathrm{CO}_{2}$ exposure. Consequently, high $\mathrm{pCO}_{2}$ reduced the scope for growth in A. rubens. Growth rates decreased substantially with increasing $\mathrm{pCO}_{2}$ and were reduced even at $\mathrm{pCO}_{2}$ levels occurring in the habitat today (e.g. during upwelling events). Sea stars were not able to acclimate to higher $\mathrm{pCO}_{2}$, and growth performance did not recover during the long-term experiment. Therefore, the top-down control exerted by this keystone species may be diminished during periods of high environmental $\mathrm{pCO}_{2}$ that already occur occasionally and will be even higher in the future. However, some individuals were able to grow at high rates even at high $\mathrm{pCO}_{2}$, indicating potential for rapid adaption. The selection of adapted specimens of $A$. rubens in this seasonally acidified habitat may lead to higher $\mathrm{CO}_{2}$ tolerance in adult sea stars of this population compared to the juvenile stage. Future studies need to address the synergistic effects of multiple stressors such as acidification, warming and reduced salinity, which will simultaneously impact the performance of sea stars in this habitat.
\end{abstract}

KEY WORDS: Ocean acidification $\cdot \mathrm{CO}_{2} \cdot$ Predation $\cdot$ Metabolism $\cdot$ Calcification $\cdot$ Sea star $\cdot$ Asterias rubens $\cdot$ Selection $\cdot$ Juvenile

\section{INTRODUCTION}

Seawater acidification, driven by increasing atmospheric $\mathrm{CO}_{2}$ concentrations, is known to gradually be increasing in the open ocean (Doney et al. 2009). By the end of the century, a reduction in seawater $\mathrm{pH}$ by about 0.4 units is expected (Caldeira \& Wickett 2005). In contrast, coastal and estuarine habitats, while also prone to a progressive shift towards lower $\mathrm{pH}$, already exhibit a large variability in $\mathrm{CO}_{2}$ partial pres- sure $\left(\mathrm{pCO}_{2}\right)$ and $\mathrm{pH}$ today. The levels, at least transiently, approach or even exceed the predicted shift over the next decades of these variables in the open ocean (Wootton et al. 2008, Hofmann et al. 2010, Yu et al. 2011, McElroy et al. 2012, Duarte et al. 2013). The western Baltic Sea is an example of such a habitat with elevated and fluctuating levels of $\mathrm{pCO}_{2}$ (Thomsen et al. 2010, 2013, Saderne et al. 2013).

During summer and autumn, the strong stratification of the water column in the Baltic inhibits gas 
exchange between bottom water and atmosphere, leading to a low $\mathrm{pO}_{2}$ and high $\mathrm{pCO}_{2}$ below the pycnocline. Occasional upwelling of these water masses can drastically elevate surface $\mathrm{pCO}_{2}$ to levels exceeding $3000 \mu \mathrm{atm}$ (Thomsen et al. 2010, 2013). Similar carbonate system fluctuations by, e.g., upwelling events have been reported for a number of coastal and estuarine environments worldwide (Feely et al. 2010, Waldbusser et al. 2011). Future increases of atmospheric $\mathrm{CO}_{2}$ concentrations will not only amplify the mean, but also the variability of $\mathrm{pCO}_{2}$ in seasonally hypoxic habitats such as the western Baltic (Melzner et al. 2013).

Ocean acidification stress is known to affect the performance of marine organisms and especially calcifiers (Kroeker et al. 2010). The stress tolerance, however, may differ between larval, juvenile and adult stages (Dupont et al. 2010b). This is especially observable for marine benthic invertebrates with pelagic larvae, which in most cases are more sensitive to environmental stress than adults and early juveniles (Pechenik 1999, Pineda et al. 2012). It has been predicted that ocean acidification will impact marine communities within the next decades (e.g. Hall-Spencer et al. 2008). This impact, however, will vary among species (Kroeker et al. 2010) and across life-history stages of the same species (reviews by Dupont et al. 2010b, Byrne 2011, Ross et al. 2011). In addition, negative and positive effects of trans-generational acclimation to elevated $\mathrm{pCO}_{2}$ on egg production and larval performance have been reported for echinoderms and molluscs, indicating that longterm and multi-generation studies are needed for better assessment of species' vulnerability to ocean acidification (Parker et al. 2012, Dupont et al. 2013). Organisms from acidified and fluctuating regions such as the western Baltic have been demonstrated to be quite robust to changes in seawater $\mathrm{pCO}_{2}$, which might result from adaptation to the present levels of acidification typical of their habitat (Thomsen \& Melzner 2010, Thomsen et al. 2010, Franke \& Clemmesen 2011, Appelhans et al. 2012, Pansch et al. 2012, 2014).

In the western Baltic, Asterias rubens is one of the ecologically most important predators of the blue mussel Mytilus edulis. Its mean annual biomass constitutes up to $12 \%$ of the entire biomass of benthic macroinvertebrates in Kiel Bight (Nauen 1979). Therefore, any negative impact on this species may have considerable consequences at an ecosystem level. As the genus Asterias is also widely distributed in coastal areas of the North Sea and the western Atlantic in general (Vevers 1949,
Nauen 1979), knowledge about the impacts of environmental stress on this species is of great ecological relevance.

Adult sea stars are relatively tolerant to moderate levels of elevated $\mathrm{pCO}_{2}$, and, in a number of earlier studies, their performance was not significantly reduced: in a $10 \mathrm{wk}$ experimental trial with adult specimens of $A$. rubens from Kiel Fjord, food consumption and growth rates were not impacted by a moderately elevated $\mathrm{pCO}_{2}$ of $1250 \mu \mathrm{atm}$, but decreased significantly at higher levels (3500 $\mu \mathrm{atm}$; Appelhans et al. 2012). Arm regeneration, righting response and growth of Luidia clathrata were not affected by a $\mathrm{pCO}_{2}$ of $780 \mu \mathrm{atm}$ (Schram et al. 2011), and metabolism was not significantly changed by a $\mathrm{pH}$ of 7.8 $\left(\mathrm{pCO}_{2}\right.$ of about 750 patm) in Parvulastra exigua (McElroy et al. 2012). These observations for adults are in line with the results reported for juveniles of Pisaster ochraceaus, showing that moderate $\mathrm{pCO}_{2}$ (780 $\mu \mathrm{atm}, \mathrm{pH}$ 7.7) slightly increases growth (Gooding et al. 2009).

In contrast, early planktonic life stages of the sea stars Patiriella regularis and Odontaster validus suffer from moderately elevated $\mathrm{pCO}_{2}$ and exhibited reduced developmental performance and survival (Gonzales-Bernat et al. 2013, Byrne et al. 2013). In a lecithotrophic species, however, elevated $\mathrm{pCO}_{2}$ enhanced growth in both non-calcified larvae and calcifying juveniles (Dupont et al. 2010a).

The present study addresses the questions whether (1) juvenile A. rubens react more sensitively to elevated $\mathrm{pCO}_{2}$ than adults and (2) whether long-term acclimation can lead to a recovery in performance. We first performed a $39 \mathrm{wk}$ experiment in order to test for long-term acclimation. Secondly, a $6 \mathrm{wk}$ experiment was conducted as replication, using slightly older animals from another year and slightly later in the season. This allowed for a comparison of all sea stars' growth, feeding and activity between the 2 experiments. Additionally, the short-term experiment provided results from physiological parameters in order to further understand physiological mechanisms underlying growth.

\section{MATERIALS AND METHODS}

The long-term experiment with an experimental duration of 39 wk (Expt 1) was performed from September 2009 until June 2010, and the short-term experiment with an experimental duration of $6 \mathrm{wk}$ (Expt 2) was performed from October to December 2010 at the GEOMAR institute in Kiel, Germany. In 
both experiments, we investigated growth, feeding rates and prey size preferences. Metabolic rates and the budgeting of physiological energetics were determined in the short-term experiment only.

\section{Organism collection}

For Expt 1, juvenile Asterias rubens were sampled on 31 August 2009 in Kiel Fjord (western Baltic Sea) via manual collection from up to $1 \mathrm{~m}$ water depth. The sea stars were selected to be of a size of $9.5 \pm$ $1 \mathrm{~mm}$ (range: 8 to $11.5 \mathrm{~mm}$ ) in outer diameter (longest distance of arm tips) and weighed $68.5 \pm 17.1 \mathrm{mg}$ wet mass (WM; range: 42 to $113 \mathrm{mg}$ ). The sea stars for Expt 2 were sampled later in the season from 4 to 7 October 2010 in Kiel Fjord. Therefore, sea stars were slightly larger with $21.5 \pm 3.5 \mathrm{~mm}$ (range: 18 to $25 \mathrm{~mm}$ ) and weighed $447.78 \pm 129.30 \mathrm{mg}$ WM (range: 270 to $860 \mathrm{mg}$ ). In both experiments, specimens were stored in a large tank with aerated flow-through water from Kiel Fjord and fed ad libitum with living mussels (Mytilus edulis) for $2 \mathrm{~d}$ (Expt 1) and $10 \mathrm{~d}$ (Expt 2) prior to placing them individually in the experimental units (EUs). Subsequently, animals were distributed randomly to the $\mathrm{CO}_{2}$ treatments, and no significant differences in start size and wet mass were detected.

\section{Experimental incubations}

The set-up of both experiments follows the one described by Appelhans et al. (2012). We established a flow-through of seawater (5 to $6 \mathrm{l} \mathrm{h}^{-1}$ ) that was pumped from Kiel Fjord through sand filters into 3 inter-connected header-tanks, and into the EUs (2 1 plastic aquaria). Three different treatment levels were achieved by bubbling pressurised air with 390, 1120 and 4000 ppm $\mathrm{CO}_{2}$ concentration (high, medium and low treatments, respectively) into the header-tanks, and additionally into the EUs. This led to mean calculated $\mathrm{CO}_{2}$ concentrations of

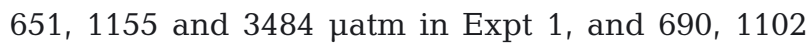
and 3128 ratm in Expt 2. Each treatment level was replicated 15 (Expt 1) or 18 (Expt 2) times. The applied $\mathrm{CO}_{2}$ levels are ecologically relevant for the investigated Asterias population since they are within the observed and predicted range of $\mathrm{CO}_{2}$ variability in Kiel Fjord (Thomsen et al. 2013). They correspond to future annual mean values (1120 $\mu \mathrm{atm})$ and to $\mathrm{pCO}_{2}$ levels which are predicted to occur in future upwelling events in this region in

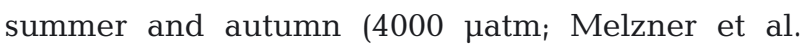
2013).

The treatment with elevated $\mathrm{pCO}_{2}$ resulted in an undersaturation of the seawater with respect to calcite and aragonite (Table 1). Temperature and salinity varied according to the natural variability in Kiel Fjord (Table 1).

\section{Carbonate system monitoring}

In both experiments, $\mathrm{pH}_{\mathrm{NBS}}$ (National Bureau of Standards scale) was measured weekly using a WTW pH meter and a Sentix 81 electrode. Temperature and salinity were measured weekly (WTW Cond 340i and a TetraCon 325 electrode). We calculated carbonate system parameters from water samples taken from 3 randomly chosen EUs per treatment level on a monthly (Expt 1) or weekly (Expt 2) basis. Water samples were analysed for total dissolved inorganic carbon $\left(C_{\mathrm{T}}\right)$ and $\mathrm{pH}_{\mathrm{T}}$ (total scale) directly after each sampling. $C_{\mathrm{T}}$ was measured using an AIRICA system (Marianda) via a LI-COR 7000 infra-red $\mathrm{CO}_{2} / \mathrm{H}_{2} \mathrm{O}$ analyser.

Measured $C_{\mathrm{T}}$ values were corrected using the Dickson seawater standard as reference material (Dickson et al. 2003). $\mathrm{pH}_{\mathrm{T}}$ was determined in a water bath $\left(21.6^{\circ} \mathrm{C}\right)$ using a Metrohm 6.0262.100 electrode calibrated with Tris/AMP seawater buffers mixed for a salinity of 15. Carbonate system parameters were calculated from measured values using CO2SYS (Pierrot et al. 2006). The values for $\mathrm{K} 1, \mathrm{~K} 2$ and $\mathrm{KHSO}_{4}$ constants were chosen according to Roy et al. (1993) (see Table 1 for values).

\section{Growth and calcification}

We monitored the sea stars' length (maximum diameter between opposing arm tips, determined via a caliper) and biomass increase (wet mass, WM) every 6th week and at the end of the experimental period in Expt 1 and weekly in Expt 2.

Eleven (Expt 1) and 18 (Expt 2) sea stars per treatment level were stored at $-20^{\circ} \mathrm{C}$ for $2 \mathrm{~d}$, then dried at $80^{\circ} \mathrm{C}$ for a minimum of $24 \mathrm{~h}$ and, subsequently, placed in a muffle furnace at $500^{\circ} \mathrm{C}$ for $24 \mathrm{~h}$. Skeletal calcification was determined by calculating the ash weight to dry weight ratio. Since pilot studies showed no significant size-dependent differences of calcified structures in specimens from Kiel Fjord in the size range of the experimental specimens $\left(\mathrm{r}^{2}=0.10, \mathrm{p}=\right.$ $0.09)$, values were not corrected for sea star biomass. 


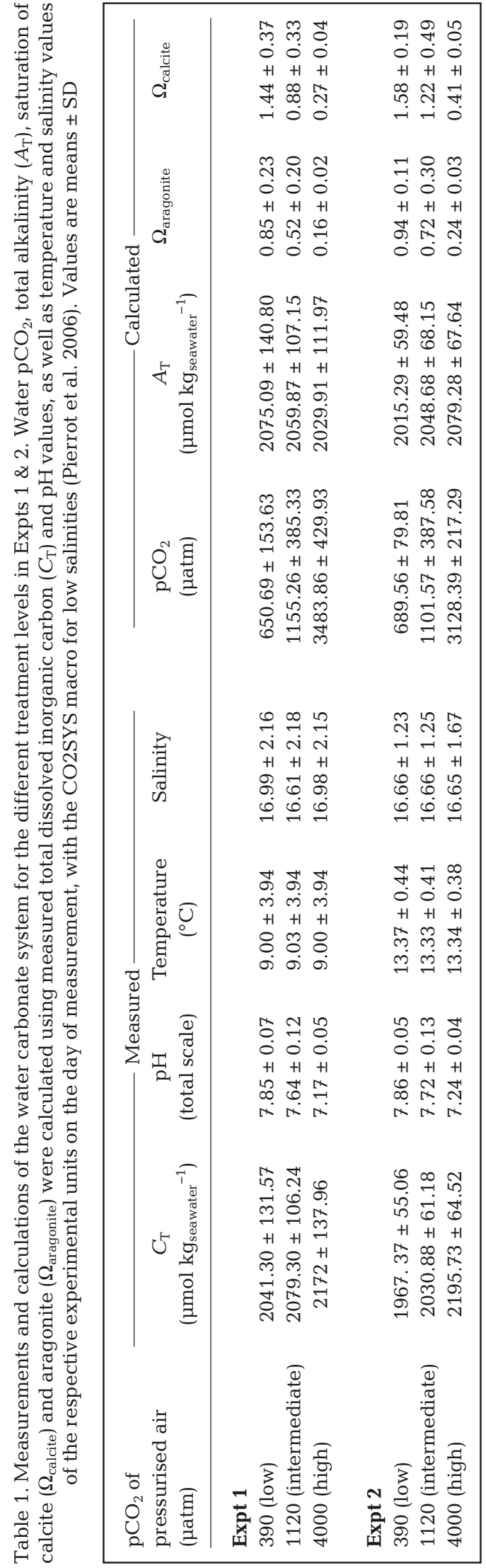

\section{Feeding}

Sea stars were fed ad libitum with living $M$. edulis from their original habitat. Five to six equally sized mussels were offered at the same time and were substituted by fresh specimens weekly or sooner, if entirely consumed. The mussel size offered was adjusted to sea star size at the time of feeding. In Expt 1, mussel size was chosen to be equal to and, in Expt 2, to be $10.0 \pm 1.0 \mathrm{~mm}$ smaller than the total sea star diameter, since larger $A$. rubens are known to consume mussels of up to their own body size (Sommer et al. 1999).

To evaluate the prey mass consumed, 5 mussels of each size class were frozen and soft tissue (somatic) dry mass was determined.

At the end of Expt 1, a feeding preference assay was performed to assess whether the stress treatment affected the preferably chosen mussel size (mean \pm $\mathrm{SD})$. Mussels of the size classes $10.0( \pm 1.0), 20.0$ $( \pm 1.0), 30.0( \pm 1.5)$ and $40.0( \pm 1.5) \mathrm{mm}$ were fed ad libitum to A. rubens, and the number of mussels consumed in each size class was documented. The sea stars were left to feed for $27 \mathrm{~d}$. Of each size class 10 mussels were again analysed for soft tissue dry weight prior to the feeding preference assay in order to calculate the total amount of soft tissue consumed by each sea star.

To compare weight-corrected feeding across treatment levels in Expt 2, the weight differences between experimental animals from the different treatment levels had to be considered. To avoid weight-dependent bias, only the consumption rates of 12 sea stars per treatment level, which did not significantly differ in weight, were used for the feeding assays. We then calculated mean weight-corrected consumption rates (wccr) such that:

$$
\mathrm{wccr}=\frac{\text { Mussel dry weight consumed } \mathrm{wk}^{-1}}{\text { Sea star wet weight in the respective week }}
$$

\section{Righting response}

Righting responses were determined at the end of Expts $1 \& 2$ and additionally after $3 \mathrm{wk}$ in Expt 2 . Individuals were placed on their aboral side. The time needed for the righting process was then measured. This includes the time to turn back to the oral side, the placement of all arms back on the aquarium floor and the latency period before turning activity commenced. This was done 3 times in Expt 1 and once in Expt 2. As larger animals need more time for 
righting, the time required by each individual was corrected for biomass using a size factor. This size factor was achieved by measuring the righting response of $25 \mathrm{~A}$. rubens specimens ranging in size from 0.2 to $15 \mathrm{~g}$ wet mass that were collected directly from the fjord. The natural relationship between biomass and righting response was:

$$
\begin{gathered}
\text { Righting (seconds needed to turn around })= \\
19.1 \times \text { biomass }(\mathrm{g} \text { wet mass })+72.7 \\
\left(\mathrm{r}^{2}=0.64, \mathrm{p}<0.001\right)
\end{gathered}
$$

The righting response was then given as a corrected righting response (crr):

$$
\mathrm{ccr}=\frac{\text { Measured righting response }}{\text { Righting response of non-treated star of equal size }}
$$

\section{Aerobic metabolism}

In Expt 2, respiration rates of the sea stars were determined in closed $250 \mathrm{ml}$ glass respirometers, which were kept at a constant temperature of $13^{\circ} \mathrm{C}$ in a water bath. Prior to the placement of an animal into the respirometer, it was filled with $0.2 \mu \mathrm{m}$ filtered seawater equilibrated to treatment $\mathrm{pCO}_{2}$. A magnetic stirrer was used to gently mix the water body within the respirometer. Decreasing oxygen concentrations of the water were recorded using $\mathrm{O}_{2}$-sensitive dye spots glued onto the inner side of the respirometer and an optic fibre connected to an Oxy4-mini instrument (Presens). Two-point calibration was performed with air-saturated water for $100 \%$ and using $100 \mathrm{mg} \mathrm{Na} \mathrm{SO}_{4}$ per $10 \mathrm{ml}$ of water for the $0 \%$ point calibration, according to the manufacturer's instructions. Depending on animal size, measurements lasted for 1.5 to $3 \mathrm{~h}$ in order to prevent oxygen concentration from falling below $90 \%$ air saturation. Following the respiration measurement, the animal was removed from the respirometer. Two duplicate water samples were taken for determination of $\mathrm{NH}_{4}^{+}$excretion rates prior to and at the end of the incubation period. Subsequently, the small water deficit $(10 \mathrm{ml})$ was replenished with filtered seawater and the respirometer was closed again to measure bacterial background respiration over $30 \mathrm{~min}$, in which the bacterial control decreased by about $1 \%$ air saturation. For calculation of oxygen consumption, the linear decrease of the $\mathrm{O}_{2}$-concentration was considered for further analysis and bacterial respiration was subtracted. In 2 cases with measurements of very small sea stars (wet mass: 0.2 to $0.3 \mathrm{~g}$ ), bacterial respiration exceeded total respiration. In order not to bias the outcome towards high values by deleting these apparent outliers, the lowest negative value in $\mathrm{O}_{2}$-consumption (net production) was used as the system error and added to all end-values. Sea star respiration is known to vary non-linearly with body mass (e.g. Cole \& Burggren 1981). In order to account for size-dependent differences in respiration rates and size differences between treatment levels, only respiration rates of 12 sea stars per treatment level, which did not significantly differ in weight, were used for comparison.

\section{$\mathrm{NH}_{4}{ }^{+}$excretion}

In Expt 2, $\mathrm{NH}_{4}{ }^{+}$excretion rates were calculated from the differences in $\mathrm{NH}_{4}{ }^{+}$concentrations measured in the water before and following the respiration measurement. Two $10 \mathrm{ml}$ water samples were taken before and after sea star incubation. Measurements of $\mathrm{NH}_{4}{ }^{+}$concentration were performed according to Holmes et al. (1999) by addition of $2.5 \mathrm{ml}$ of a reagent containing orthophthaldialdehyde, $\mathrm{Na}_{2} \mathrm{SO}_{3}$ and $\mathrm{Na}_{2} \mathrm{~B}_{4} \mathrm{O}_{7} \cdot 10 \mathrm{H}_{2} \mathrm{O}$. Samples were measured using a Kontron SFM25 fluorometer (Kontron Instruments) at excitation and emission wavelengths of 360 and $422 \mathrm{~nm}$, respectively, $2 \mathrm{~h}$ after addition. The O:N ratio was calculated by dividing the molar oxygen consumption rate by the molar $\mathrm{NH}_{4}{ }^{+}$excretion rate. As with metabolic rate determinations, only data of the same 12 equally sized sea stars per treatment level were analysed.

\section{Scope for growth}

The energy available for growth processes (scope for growth, SfG) was calculated for the last 2 wk of the experimental phase of Expt 2 according to the formula:

$$
\mathrm{SfG}=E-R-U
$$

where $E$ is the energy uptake by feeding, $R$ is the energy turnover by respiration and $U$ is the energy turnover by ammonium excretion.

Energy uptake by consumption of mussel dry mass (18.85 $\mathrm{J} \mathrm{mg}^{-1}$ ) was calculated according to Brey et al. (1988), and estimates on the energy turnover by respi-

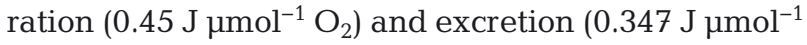
$\mathrm{NH}_{4}{ }^{+}$excreted) were taken from Gnaiger (1983) and Elliott \& Davison (1975), respectively. Biomass gain of sea stars was converted into energy equivalents using 9.46 $\mathrm{J} \mathrm{mg}^{-1}$ according to Brey et al. (1988). 


\section{Statistical analyses}

Data were analysed using repeated-measures ANOVA for growth, food consumption and the range of mussels consumed in the feeding assay (Expt 1). One-way ANOVA was conducted for all other comparisons, using Tukey's HSD (honestly significant difference) post hoc test. Correlation of energy uptake and biomass production was analysed using ANOVA. All data were initially tested for normal distribution using the Shapiro-Wilk's $W$-test. If data were non-normally distributed, the Box-Cox procedure identified the simplest transformation to achieve normality. Homogeneity of variances was assessed using Levene's test. If data did not meet requirements of sphericity (Mauchly's test), p-values were corrected using the Greenhouse-Geisser correction. If the required assumptions were not achieved, parametric tests were carried out with a lowered $\alpha$ level of significance to $\mathrm{p}<0.01$ (see e.g. Underwood 1997, Wakefield \& Murray 1998). Percentage data were arcsine square-root transformed before attempting other transformation. If missing data values resulted in an unbalanced design, random values of other treatment levels were deleted to achieve balance.

\section{RESULTS}

\section{Mortality, growth and calcification (Expts 1 \& 2)}

Only 2 cases of mortality occurred (Expt 1 ). Here, 1 out of 15 sea stars (Asterias rubens) died at each of the low and high treatment levels.

In Expt 1, the significantly greatest biomass gain was observed under low conditions, with a 2 -fold decrease in biomass gain at the intermediate level and a 5-fold decrease at the high $\mathrm{pCO}_{2}$ level (Fig. 1a, Table 2). The biomass of specimens at the low and high treatment levels differed significantly from Week 24 onwards, while the biomass of sea stars at the low and intermediate treatment levels differed from Week 39 onwards (Fig. 1a, Table 2).

Over the 6 wk period of Expt 2, the gain in biomass was significantly highest at low conditions, with a 3-fold decrease at the high $\mathrm{pCO}_{2}$ level (Fig. 1b, Table 2). Sea stars at the low treatment level differed significantly from those at the high level from Week 4 onwards (Fig. 1b, Table 2). At intermediate $\mathrm{pCO}_{2}$, individuals did not differ significantly either from the low or the high levels until the end of the experiment.
In both experiments, the mean biomass was at all times lowest in sea stars from the high $\mathrm{pCO}_{2}$ level and highest in the low $\mathrm{pCO}_{2}$ treatments (Fig. 2). Calcification ( $\%$ of calcified material of total dry weight) did not significantly differ between the different treatments in either experiment (Table 2).

\section{Feeding (Expts $1 \&$ 2)}

In the feeding assay of Expt 1, mussel (Mytilus edulis) consumption rates by sea stars were 5 times higher in the low $\mathrm{pCO}_{2}$ treatment in comparison to the intermediate level and 9 times higher than at the high level $(\mathrm{p}<0.0001$; Fig. 2a, Table 2). The consumption during the assay was not correlated to the initial size of the sea star, but was affected by $\mathrm{pCO}_{2}$ treatment.
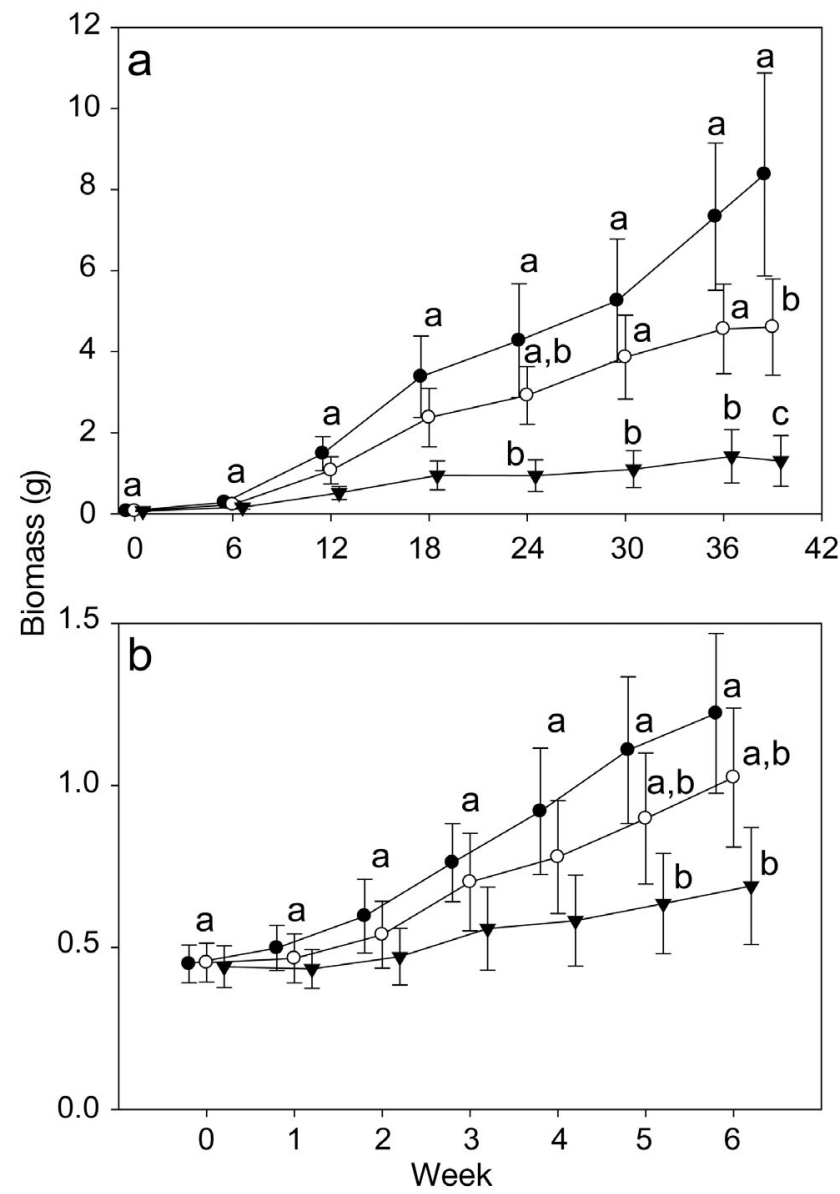

Fig. 1. Asterias rubens. Mean growth of sea stars over (a) 39 wk (Expt 1) and (b) 6 wk (Expt 2) at different $\mathrm{pCO}_{2}$ treatment levels (see Table 1; 0: low, O: intermediate, $\mathbf{\nabla}$ : high). Vertical bars denote $\pm 95 \%$ CI. Groups with different lowercase letters significantly differ at $p \leq 0.01$ (repeatedmeasures ANOVA, Tukey's HSD) 
Table 2. ANOVA and ANCOVA results. Analyses performed with different response variables and the dependent fixed factor $\mathrm{pCO}_{2}$ (3 levels). For non-parametric data, the $\alpha$-level was adjusted to 0.01. Bold: statistically significant results ( $\mathrm{p} \leq 0.01$ )

\begin{tabular}{|c|c|c|c|c|c|c|}
\hline & $\alpha$ & $\mathrm{df}$ & MS & $F$ & $\mathrm{p}$ & Partial $\eta^{2}$ \\
\hline \multicolumn{7}{|l|}{ Long-term experiment (Expt 1) } \\
\hline Increase in biomass - over time & 0.01 & 14 & 23800000 & 15.06 & $<0.0001$ & 0.46 \\
\hline Righting response & 0.05 & 2 & 0.05 & 1.46 & 0.25 & 0.07 \\
\hline Mussel consumption — total & 0.01 & 2 & 232.14 & 18.00 & $<0.0001$ & 0.50 \\
\hline Mussel consumption — per size class (interactions) & 0.01 & 6 & 1.55 & 1.75 & 0.12 & 0.12 \\
\hline Calcification & 0.05 & 2 & 0.40 & 0.02 & 0.99 & $<0.01$ \\
\hline \multicolumn{7}{|l|}{ Short-term experiment (Expt 2) } \\
\hline Increase in biomass - over time (interactions) & 0.01 & 12 & 0.19 & 6.19 & $<0.0001$ & 0.20 \\
\hline Righting response Week 3 & 0.05 & 2 & 0.01 & 0.22 & 0.8 & 0.09 \\
\hline Righting response Week 6 & 0.05 & 2 & 0.31 & 2.45 & 0.1 & 0.01 \\
\hline Mussel consumption — total & 0.01 & 2 & 9.68 & 6.54 & $<0.01$ & 0.20 \\
\hline Mussel consumption — over time (interactions) & 0.01 & 10 & 295.94 & 2.66 & $<0.01$ & 0.09 \\
\hline Weight-corrected mussel consumption & 0.01 & 2 & 1.00 & 1.03 & 0.37 & 0.05 \\
\hline Respiration & 0.05 & 2 & 1.24 & 0.58 & 0.56 & 0.03 \\
\hline $\mathrm{NH}_{4}^{+}$excretion & 0.05 & 2 & 0.64 & 0.75 & 0.48 & 0.04 \\
\hline $\mathrm{O}: \mathrm{N}$ ratio & 0.05 & 2 & 0.98 & 0.03 & 0.97 & $<0.01$ \\
\hline Scope for growth & 0.01 & 2 & 88253.00 & 6.60 & $<0.01$ & 0.23 \\
\hline Growth efficiency & 0.05 & 2 & 4250000 & 2.31 & 0.11 & 0.26 \\
\hline Calcification & 0.01 & 2 & 120.70 & 0.48 & 0.62 & 0.01 \\
\hline
\end{tabular}

There was no significant interaction between consumed mussel sizes and treatment level of sea stars in the feeding assay of Expt 1 (Fig. 2c, Table 2). Nevertheless, sea stars from the intermediate and high treatment levels almost exclusively consumed mussels of the $2 \mathrm{~cm}$ size class, while sea stars from the low $\mathrm{CO}_{2}$ level primarily consumed mussels of the 3 and $4 \mathrm{~cm}$ size classes.

In Expt 2, the overall mean consumption over the 6 wk period differed significantly only between the low and high treatment levels (Fig. 2b, Table 2). Sea stars at $690 \mu \mathrm{atm}$ consumed twice as much biomass as sea stars at 3128 uatm. Consumption levels of mussels followed a less consistent pattern over time (Fig. 2d, Table 2) than did the sea star's growth. Significant differences between groups in terms of the amount of biomass consumed per week changed on a weekly basis.

When consumption rates were corrected for weight, there was no significant difference in consumption between $\mathrm{pCO}_{2}$ levels (Table 2).

\section{Righting response (Expt 2)}

The period for the righting itself increased with size. Therefore, righting time was corrected for size using a correlation obtained from control animals collected in the field. Sea stars from all $\mathrm{pCO}_{2}$ treatments were able to turn back on their oral side.
Righting time was highly variable for the individuals, but was not impacted by $\mathrm{pCO}_{2}$ treatment either in Expt 1 or in Expt 2 (Table 2).

\section{Respiration, $\mathrm{NH}_{4}{ }^{+}$excretion and scope for growth (Expt 2)}

No significant differences in respiration and $\mathrm{NH}_{4}{ }^{+}$ excretion rates were found between the $\mathrm{pCO}_{2}$ treatments in Expt 2 (Table 2). As a result, the O:N ratio did not differ significantly between treatments $(p>$ 0.05; Table 2).

The SfG among sea stars at the low $\mathrm{pCO}_{2}$ level was 4 times higher than that for sea stars at the high level (Fig. 3a, Table 2). The growth efficiency of biomass gain of sea stars in relation to their energy uptake did not differ significantly between the $\mathrm{pCO}_{2}$ treatments (Fig. 3b, Table 2).

\section{DISCUSSION}

\section{Effects at the species level}

Our study reveals that juvenile sea stars (Asterias rubens) react sensitively to increased $\mathrm{pCO}_{2}$. Whereas survival was not affected even at moderately elevated $\mathrm{pCO}_{2}$ levels, we observed significant reductions in food consumption and growth. Calcification does not 

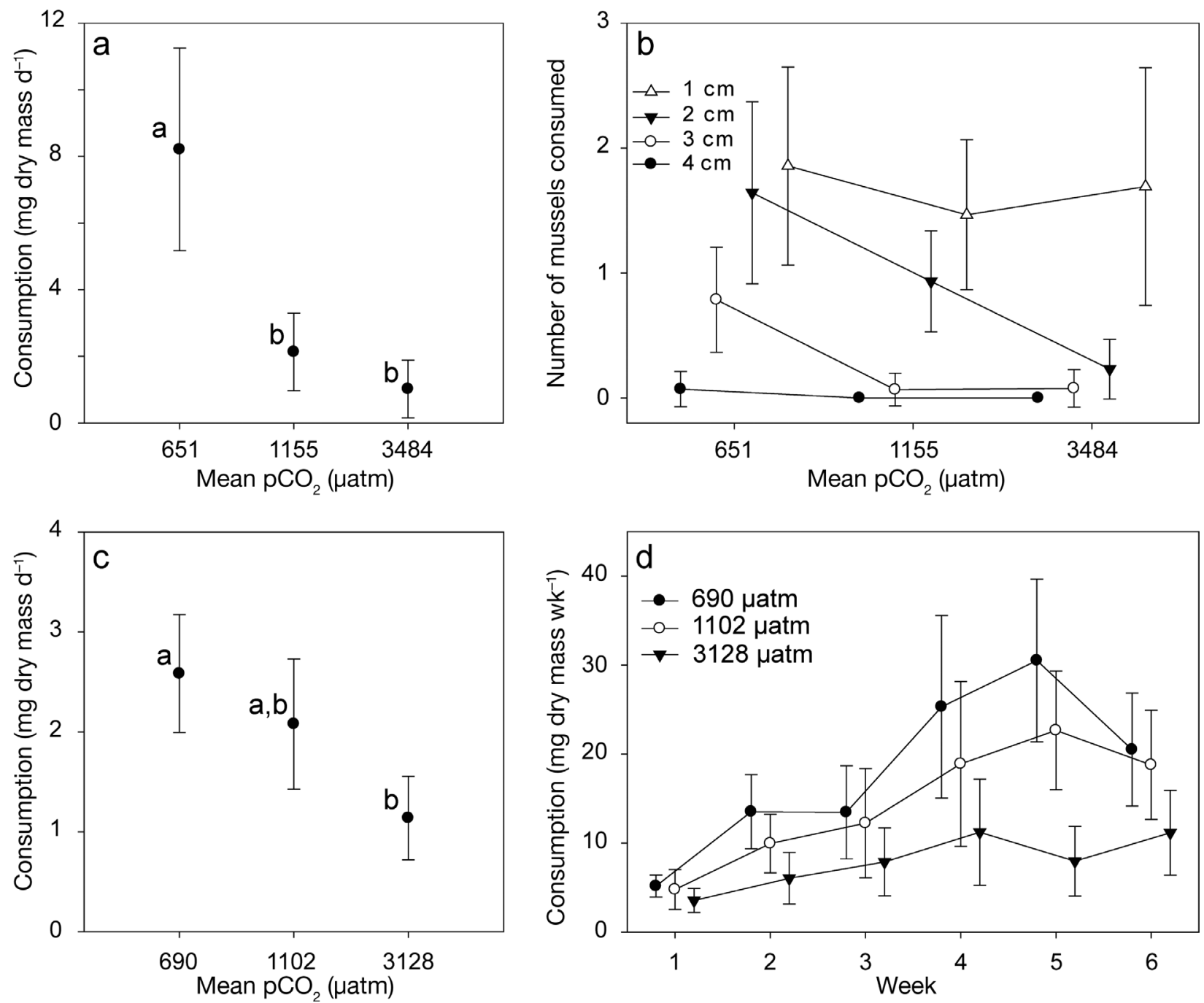

Fig. 2. Asterias rubens feeding on Mytilus edulis. At different treatment levels, mean consumption (a) and consumed number of mussels by size classes (b) during feeding assays following Expt 1, and mean consumption (c) and weekly consumption (d) during the 6 wk experimental period of Expt 2. Vertical bars denote $\pm 95 \%$ CI. (a,b) Results from 1 -way ANOVA followed by post hoc testing (Tukey's HSD). (c,d) Results from repeated-measures ANOVA testing for interactions. Groups with different lowercase letters significantly differ at $\mathrm{p} \leq 0.01$

seem to be directly affected by elevated $\mathrm{pCO}_{2}$, but is indirectly reduced due to decreased growth rates, resulting from overall energy limitation by lowered feeding. However, due to the variance response between individuals, significant differences between low and intermediate $\mathrm{pCO}_{2}$ treatments were only observed after a long experimental period of $39 \mathrm{wk}$. The results of the present study using juvenile sea stars do not seem to support the previously stated hypothesis that the population in Kiel Fjord is pre-adapted to elevated $\mathrm{pCO}_{2}$ and is, therefore, less impacted, at least by moderate levels, of increased $\mathrm{pCO}_{2}$ (Appelhans et al. 2012). Although collected from the same habitat, the sensitivity of individual sea stars varied markedly.
As the planktonic larvae of sea stars can enter the fjord via drift-water originating from the Kattegat (Denmark), the settled juveniles do not necessarily originate from the Kiel Fjord population itself. Specimens in this area are exposed to not only variable but also strongly elevated $\mathrm{pCO}_{2}$ levels of on average 700 uatm (Thomsen et al. 2013). Consequently, the selection of $\mathrm{CO}_{2}$ tolerant specimens at the juvenile stages may lead to higher overall performance at the adult stage. In contrast, less tolerant and slow-growing specimens may not reach the adult life stage or exhibit a normal size range; such specimens were thus excluded from previous experiments because of their small size (Appelhans et al. 2012). 

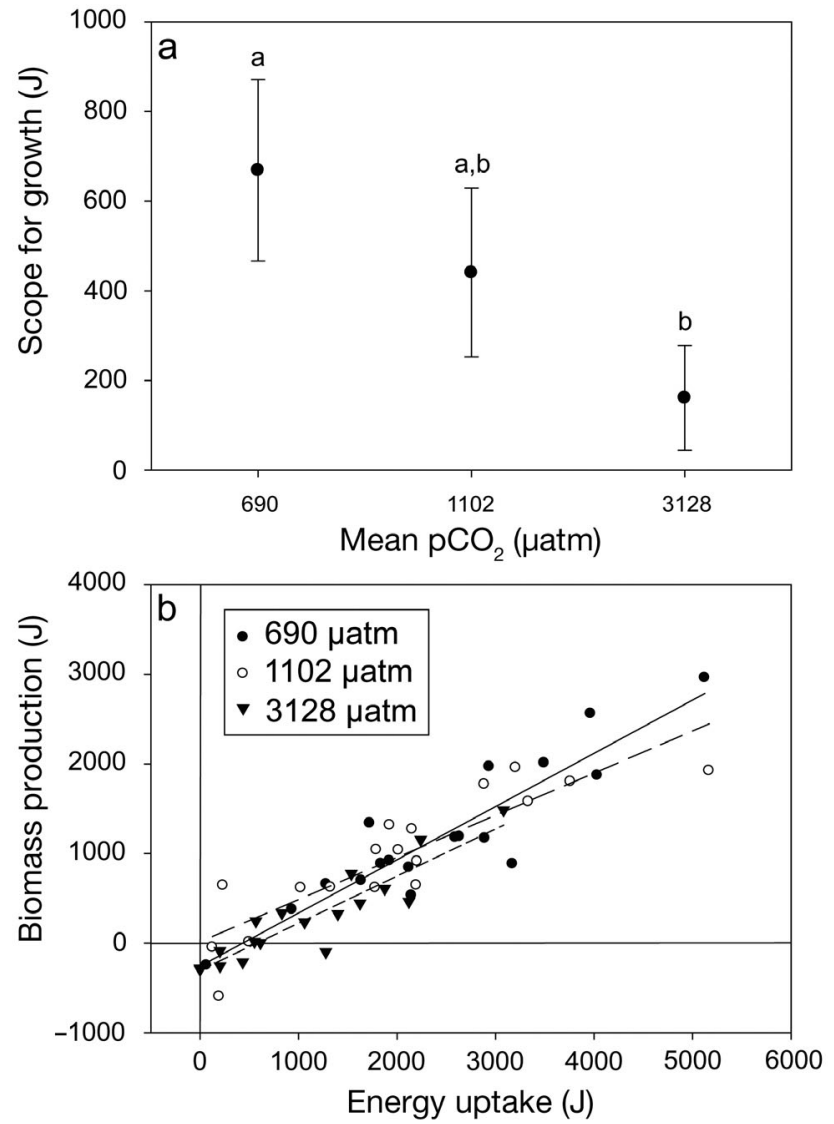

Fig. 3. Asterias rubens. Mean scope for growth (a) of sea stars during the last $2 \mathrm{wk}$ of the $6 \mathrm{wk}$ experimental period of Expt 2 over the different treatment levels. Vertical bars denote $\pm 95 \%$ CI. Results from 1-way ANOVA followed by post hoc testing (Tukey's HSD). Groups with different lowercase letters significantly differ at $p \leq 0.01$. (b) Energy equivalents of consumed mussel (Mytilus edulis) biomass and biomass production of sea stars in Expt 2

During the entire long-term exposure period, no signs of acclimation of growth performance were visible. Therefore, a shorter, mechanistic experiment (Expt 2) was carried out in order to understand the physiological reason for reduced growth at elevated $\mathrm{pCO}_{2}$. The growth rates and growth rate differences obtained between treatments were similar to those in the long-term study. Slightly higher growth rates in Expt 2 corresponded to higher mean temperatures compared to Expt 1.

Similar to other studies on echinoderms, food consumption was the process primarily affected by elevated $\mathrm{pCO}_{2}$ (Siikavuopio et al. 2007, Stumpp et al. 2012, 2013), whereas the efficiency by which consumed mussel biomass could be converted into sea star biomass did not differ between $\mathrm{pCO}_{2}$ treatment levels. As a consequence of lowered food consumption and unchanged metabolic rates, the SfG de- creased in the higher $\mathrm{pCO}_{2}$ treatments. Reduced feeding rates may have resulted from a number of physiological processes, but underlying mechanisms need to be further investigated.

One explanation may be that the foraging activity of sea stars is disturbed at higher $\mathrm{pCO}_{2}$ levels. The righting response did not differ significantly between different $\mathrm{pCO}_{2}$ treatment levels, suggesting that movement capability was not impaired (Schram et al. 2011). Recent studies suggest, however, that foraging behaviour of marine invertebrates, such as crustaceans, is potentially altered under high $\mathrm{pCO}_{2}$, due to a disturbance of olfactory sensing (Briffa et al. 2012). Either the sensing of prey kairomones themselves (Rochette et al. 1994) or the processing of sensory information (Nilsson et al. 2012) may be impaired. In both cases, foraging and subsequent feeding would be reduced. Behavioural changes were not investigated in the present study, but future research will need to address this important question in detail.

It has previously been suggested that uncompensated extracellular $\mathrm{pH}(\mathrm{pHe})$ in organisms exposed to elevated $\mathrm{pCO}_{2}$ can lead to metabolic depression, which, in turn, can cause growth reductions (Pörtner et al. 2004, Michaelidis et al. 2005). A marginal downregulation of metabolic rates was observed for $A$. rubens from a North Sea population (Collard et al. 2013). In the present study, however, sea stars maintained metabolic rates at similar levels in all treatments, although pHe in this species generally decreases at elevated $\mathrm{pCO}_{2}$ (Hernroth et al. 2011, Appelhans et al. 2012, Collard et al. 2013). This result supports most studies concerning moderately elevated $\mathrm{pCO}_{2}$ (1000 to $\left.3000 \mu \mathrm{atm}\right)$ in molluscs (Beniash et al. 2010, Thomsen \& Melzner 2010) as well as in echinoderms (Wood et al. 2008, Stumpp et al. 2011, 2012, McElroy et al. 2012). Unchanged oxygen consumption in our study evidenced that the overall energy turnover was not affected. Shifts in the cellular energy budget towards higher acid-base and ion-regulatory demands under elevated $\mathrm{pCO}_{2}$ and a concomitant reduction of, e.g., protein biosynthesis cannot be excluded (Deigweiher et al. 2010). These shifts, in turn, may lead to reductions of energetically more costly processes such as feeding (McGaw \& Twitchit 2012), including mussel opening and digestion (specific dynamic action of food [SDA]; McGaw \& Twitchit 2012). Characteristically, sea stars have low basal metabolic rates and the feeding process has a pronounced impact on the overall energy budget as, compared to control rates, metabolic rates increase >2-fold when actively feeding (Vahl 1984, Hughes et al. 2011, McGaw \& Twitchit 2012). 
Elevated $\mathrm{pCO}_{2}$ might affect feeding rates due to an impairment of the mussel opening process. Sea stars 'lock' their endoskeleton to cause a mechanistic rigidness when pulling mussel shells apart using their tube feet (Christensen 1957, Norberg \& Tedengren 1995). Therefore, the ambulacral arches play an important role in the feeding process of sea stars (Eylers 1976). The costs to mechanically open mussels as primary prey constitute only about $3.5 \%$ of the total SDA costs and are therefore negligible (McGaw \& Twitchit 2012). The mechanics of feeding, however, demand the presence of certain skeletal structures the growth of which might be impaired in juvenile sea stars under acidified conditions. Nevertheless, the endoskeleton of echinoderms has no direct contact with the coelomic fluid, but is separated from it through syncytial sclerocytes and an electron dense, organic matrix coat (Märkel et al. 1989). Therefore, low pHe and $\mathrm{CaCO}_{3}$ undersaturation in the body fluid may only have limited effects on the calcification process, even under highly elevated seawater $\mathrm{pCO}_{2}$ (Appelhans et al. 2012, Stumpp et al. 2012). As we did not observe differences in the $\mathrm{CaCO}_{3}$ content or structure between the $\mathrm{CO}_{2}$ treatments, in contrast to results obtained by Gooding et al. (2009), a mechanical impairment of the feeding process was not likely to be responsible for reduced feeding rates. This is also supported by recent findings, revealing that calcification processes in sea urchins and mechanical properties of the tube feet of A. rubens are basically unaffected by ocean acidification (Collard et al. 2013, LaVigne et al. 2013).

Sea stars produce their digestive enzymes, such as proteases and amylases, in the pyloric caeca, which are surrounded by coelomic fluid (Peng \& Williams 1973, Williams 1975). These enzymes are either excreted into the stomach for extracellular digestion or remain in the caeca, where intracellular digestion and storage of nutrients takes place (Holzman et al. 1985). Especially proteases, such as trypsin, show optimal activity at alkaline $\mathrm{pH}$ values between 8 and 9 to 10 , and their activity may decrease at lower pHe levels at the site of extracellular digestion (Neurath \& Winter 1970, Adelung 1971, Peng \& Williams 1973). In contrast, mobilization of lipid stores in the pyloric caeca might not be affected, as $\mathrm{pH}$ optima for, e.g., triacylglycerol lipase activity are at much lower $\mathrm{pH}$ levels (pH 6 to 7; Oudejans et al. 1983). The observed lack of acclimation in the present long-term study might be explained by the fact that enzymatic $\mathrm{pH}$ optima do not change at the scale of an individual's life span. According to recent results for echinoderm larvae, which show a reduction of enzyme activity due to ocean acidification-induced stomach acidosis (Stumpp et al. 2013), this process could have caused reductions of feeding efficiency in $A$. rubens in the present study. This hypothesis, however, cannot explain increased food consumption by potentially compensatory feeding as observed in another sea star species at moderately elevated $\mathrm{pCO}_{2}(780$ uatm; Gooding et al. 2009).

\section{Consequences at the ecosystem level}

Seawater acidification has the potential to change ecosystem structures (Hall-Spencer et al. 2008). At the same time, many coastal habitats are characterised by high present-day $\mathrm{pCO}_{2}$ variability, which does not necessarily cause the absence of calcifying organisms (Thomsen et al. 2010, 2013). Seasonally high $\mathrm{pCO}_{2}$ levels occur naturally, and these will be further amplified by the synergistic effects of coastal hypoxia and future atmospheric $\mathrm{CO}_{2}$ increases, resulting in much higher $\mathrm{pCO}_{2}$ levels than could be expected from simple equilibration of oceanic water with increasing atmospheric $\mathrm{CO}_{2}$ concentrations (Melzner et al. 2013). As a consequence, the $\mathrm{pCO}_{2}$ levels tested in the present study will be reached regularly during summer (>1000 $\mu \mathrm{atm}$ ) and might even be exceeded during extensive upwelling events, with levels of up to 4500 ratm in autumn (Thomsen et al. 2010, Melzner et al. 2013).

Our study indicates that the overall feeding pressure by sea stars on mussels ( $M$. edulis) in the western Baltic can be expected to decrease with increasing seawater acidification. Since A. rubens is among the most important predators controlling the distribution and abundance of this dominant filter feeder (Enderlein \& Wahl 2004), considerable consequences on the ecosystem level can be expected in the future.

In our study, no acclimation of feeding and growth rates was observed during a 39 wk period, which suggests an unlikely recovery at even longer time scales. However, trans-generational acclimation may partly mitigate the impact of acidification (Miller et al. 2012, Dupont et al. 2013). In seasonally acidified habitats such as Kiel Fjord, selection of adapted phenotypes during the early benthic life stage might lead to a more acidification-resistant population, as observed for the adult life stage (Sanford \& Kelly 2011, Appelhans et al. 2012). If $\mathrm{CO}_{2}$ tolerance is heritable, selection pressure could lead to adaptation to elevated $\mathrm{pCO}_{2}$ conditions over several generations (Sunday et al. 2011). However, apart from acidification, several abiotic factors such as warming and 
desalination will impact the Baltic ecosystem simultaneously, which might exceed the species' potential for adaptation (Gräwe et al. 2013). Future research needs to investigate the synergistic effects on this key species in a multi-stressor approach.

\section{CONCLUSIONS}

We conclude that $A$. rubens from the Baltic Sea is more strongly affected by seawater acidification than previously thought. Nevertheless, survival was not lowered even under heavily acidified conditions during long-term exposure. Overall, growth strongly declined with increasing $\mathrm{pCO}_{2}$ as a consequence of reduced food uptake, and even during long-term exposure sea stars did not acclimate. The slower growth of juvenile $A$. rubens under high $\mathrm{pCO}_{2}$ may lead to reduced reproduction, with corresponding demographic consequences at the population level. Since very few predators prey on $A$. rubens in the western Baltic Sea (Nauen 1979), retarded growth will not enhance mortality (by consumers), but could trigger top-down effects. Nevertheless, we detected individual variability in the responses, with some individuals exhibiting high growth rates and development into adult stages even at highly elevated $\mathrm{pCO}_{2}$ levels. Selection pressure on resistant genotypes may thus lead to adaptation in the $A$. rubens population to elevated $\mathrm{pCO}_{2}$.

Acknowledgements. We thank the German Academic Foundation, the DFG Excellence cluster Future Ocean and the German 'Biological Impacts of Ocean Acidification (BIOACID)' funded by the Federal Ministry of Education and Research (BMBF, FKZ 03F0608A) for funding of this study. Further we thank Martin Paar for help with the maintenance of the long-term experiment, Dr. Mark Lenz for statistical advice and Mandy Kierspel for analysis of the water chemistry. Additionally, the authors thank 3 anonymous reviewers and the editor for substantially improving the quality of the manuscript.

\section{LITERATURE CITED}

> Adelung D (1971) Untersuchungen zur Häutungsphysiologie der dekapoden Krebse am Beispiel der Strandkrabbe Carcinus maenas. Helgol Wiss Meeresunters 22:66-119 Appelhans YS, Thomsen J, Pansch C, Melzner F, Wahl M (2012) Sour times: seawater acidification effects on growth, feeding behaviour and acid-base status of Asterias rubens and Carcinus maenas. Mar Ecol Prog Ser 459: 85-98

Beniash E, Ivanina A, Lieb NS, Kurochkin I, Sokolova IM (2010) Elevated level of carbon dioxide affects metabolism and shell formation in oysters Crassostrea virginica.
Mar Ecol Prog Ser 419:95-108

Brey T, Rumohr H, Ankar S (1988) Energy content of macrobenthic invertebrates - general conversion factors from weight to energy. J Exp Mar Biol Ecol 117:271-278

Briffa M, de la Haye $\mathrm{K}$, Munday PL (2012) High $\mathrm{CO}_{2}$ and marine behaviour: potential mechanisms and ecological consequences. Mar Pollut Bull 64:1519-1528

Byrne M (2011) Impact of ocean warming and ocean acidification on marine invertebrate life history stages: vulnerabilities and potential for persistence in a changing ocean. Oceanogr Mar Biol Annu Rev 49:1-42

Byrne M, Gonzalez-Bernat M, Doo S, Foo S, Soars N, Lamare M (2013) Effects of ocean warming and acidification on embryos and non-calcifying larvae of the invasive sea star Patiriella regularis. Mar Ecol Prog Ser 473:235-246

Caldeira K, Wickett ME (2005) Ocean model predictions of chemistry changes from carbon dioxide emissions to the atmosphere and ocean. J Geophys Res 110:C09S04, doi: 10.1029/2004JC002671

Christensen AM (1957) The feeding behavior of the sea star Evasterias troschelli Stimpson. Limnol Oceanogr 2: 180-197

Cole RN, Burggren WW (1981) The contribution of respiratory papulae and tube feet to oxygen uptake in the sea star Asterias forbesi (Desor). Mar Biol Lett 2:279-287

Collard M, Catarino AI, Bonnet S, Flammang P, Dubois P (2013) Effects of $\mathrm{CO}_{2}$ induced ocean acidification on physiological and mechanical properties of the starfish Asterias rubens. J Exp Mar Biol Ecol 446:355-362

- Deigweiher K, Hirse T, Bock C, Lucassen M, Pörtner HO (2010) Hypercapnia induced shifts in gill energy budgets of Antarctic notothenioids. J Comp Physiol B 180: 347-359

> Dickson AG, Afghan JD, Anderson GC (2003) Reference materials for oceanic $\mathrm{CO}_{2}$ analysis: a method for the certification of total alkalinity. Mar Chem 80:185-197

Doney SC, Fabry VJ, Feely RA, Kleypas JA (2009) Ocean acidification: the other $\mathrm{CO}_{2}$ problem. In: Annual review of marine science, Book 1. Annual Reviews, Palo Alto, CA, p 169-192

> Duarte CM, Hendriks IE, Moore TS, Olsen YS and others (2013) Is ocean acidification an open-ocean syndrome? Understanding anthropogenic impacts on seawater $\mathrm{pH}$. Estuaries Coasts 36:221-236

> Dupont S, Lundve B, Thorndyke M (2010a) Near future ocean acidification increases growth rate of the lecithotrophic larvae and juveniles of the sea star Crossaster papposus. J Exp Zool B Mol Dev Ecol 314:382-389

> Dupont S, Ortega-Martinez O, Thorndyke M (2010b) Impact of near-future ocean acidification on echinoderms. Ecotoxicology 19:449-462

> Dupont S, Dorey N, Stumpp M, Melzner F, Thorndyke M (2013) Long-term and trans-life-cycle effects of exposure to ocean acidification in the green sea urchin Strongylocentrotus droebachiensis. Mar Biol 160:1835-1843

Elliott JM, Davison W (1975) Energy equivalents of oxygenconsumption in animal energetics. Oecologia 19:195-201

Enderlein P, Wahl M (2004) Dominance of blue mussels versus consumer-mediated enhancement of benthic diversity. J Sea Res 51:145-155

Eylers JP (1976) Aspects of skeletal mechanics of the starfish Asterias forbesii. J Morphol 149:353-367

Feely RA, Alin SR, Newton J, Sabine CL and others (2010) The combined effects of ocean acidification, mixing, and 
respiration on $\mathrm{pH}$ and carbonate saturation in an urbanized estuary. Estuar Coast Shelf Sci 88:442-449

> Franke A, Clemmesen C (2011) Effect of ocean acidification on early life stages of Atlantic herring (Clupea harengus L.). Biogeosciences 8:3697-3707

Gnaiger E (1983) Appendix C. Calculation of energetic and biochemical equivalents of respiratory oxygen consumption. In: Gnaigner E, Forstner H (eds) Polargraphic oxygen sensors. Aquatic and physiological applications. Springer Verlag, Heidelberg, p 337-345

Gonzalez-Bernat MJ, Lamare M, Barker M (2013) Effects of reduced seawater $\mathrm{pH}$ on fertilisation, embryogenesis and larval development in the Antarctic seastar Odontaster validus. Polar Biol 36:235-247

> Gooding RA, Harley CDG, Tang E (2009) Elevated water temperature and carbon dioxide concentration increase the growth of a keystone echinoderm. Proc Natl Acad Sci USA 106:9316-9321

Gräwe U, Friedland R, Burchard H (2013) The future of the western Baltic Sea: two possible scenarios. Ocean Dyn 63:901-921

Hall-Spencer JM, Rodolfo-Metalpa R, Martin S, Ransome E and others (2008) Volcanic carbon dioxide vents show ecosystem effects of ocean acidification. Nature 454: 96-99

Hernroth B, Baden S, Thorndyke M, Dupont S (2011) Immune suppression of the echinoderm Asterias rubens (L.) following long-term ocean acidification. Aquat Toxicol 103:222-224

Hofmann GE, Barry JP, Edmunds PJ, Gates RD, Hutchins DA, Klinger T, Sewell MA (2010) The effect of ocean acidification on calcifying organisms in marine ecosystems: an organism-to-ecosystem perspective. In: Futuyma DJ, Shafer HB, Simberloff D (eds) Annual review of ecology, evolution, and systematics, Vol 41, Book 41. Annual Reviews, Palo Alto, CA, p 127-147

> Holmes RM, Aminot A, Kerouel R, Hooker BA, Peterson BJ (1999) A simple and precise method for measuring ammonium in marine and freshwater ecosystems. Can J Fish Aquat Sci 56:1801-1808

> Holzman TF, Russo SF, Williams DC (1985) Effects of feeding and starvation on proteolytic and tryptic activities in pyloric caecal tissues and duct fluids of the seastar Pisaster ochraceus. Mar Biol 90:55-59

> Hughes SJM, Ruhl HA, Hawkins LE, Hauton C, Boorman B, Billett DSM (2011) Deep-sea echinoderm oxygen consumption rates and an interclass comparison of metabolic rates in Asteroidea, Crinoidea, Echinoidea, Holothuroidea and Ophiuroidea. J Exp Biol 214:2512-2521

Kroeker KJ, Kordas RL, Crim RN, Singh GG (2010) Metaanalysis reveals negative yet variable effects of ocean acidification on marine organisms. Ecol Lett 13:1419-1434

> LaVigne M, Hill TM, Sanford E, Russell AD, Lenz EA, Hisfelt JD, Young MK (2013) The elemental composition of purple sea urchin (Strongylocentrotus purpuratus) calcite and potential effects of $\mathrm{pCO}_{2}$ during early life satges. Biogeosciences 10:3465-3477

> Märkel K, Roser U, Stauber M (1989) On the ultrastructure and the supposed function of the mineralizing matrix coat of sea urchins (Echinodermata, Echinoida). Zoomorphology 109:79-87

McElroy DJ, Nguyen HD, Byrne M (2012) Respiratory response of the intertidal seastar Parvulastra exigua to contemporary and near-future pulses of warming and hypercapnia. J Exp Mar Biol Ecol 416-417:1-7
McGaw IJ, Twitchit TA (2012) Specific dynamic action in the sunflower star, Pycnopodia helianthoides. Comp Biochem Physiol A Mol Integr Physiol 161:287-295

- Melzner F, Thomsen J, Koeve W, Oschlies A and others (2013) Future ocean acidification will be amplified by hypoxia in coastal habitats. Mar Biol 160:1875-1888

> Michaelidis B, Ouzounis C, Paleras A, Pörtner HO (2005) Effects of long-term moderate hypercapnia on acid-base balance and growth rate in marine mussels Mytilus galloprovincialis. Mar Ecol Prog Ser 293:109-118

Miller GM, Watson SA, Donelson JM, McCormick MI, Munday PL (2012) Parental environment mediates impacts of increased carbon dioxide on a coral reef fish. Nat Clim Change 2:858-861

Nauen CE (1979) Populationsdynamik und Ökologie des Seesterns Asterias rubens L. in der Kieler Bucht. PhD thesis, Christian-Albrechts-Universität, Kiel

> Neurath H, Winter WP (1970) Purification and properties of a trypsin-like enzyme from the starfish Evasterias trochelii. Biochemistry 9:4673-4679

Nilsson GE, Dixson DL, Domenici P, McCormick MI, Sørensen C, Watson SA, Munday PL (2012) Near-future carbon-dioxide levels alter fish behaviour by interfering with neurotransmitter function. Nature Clim Change 2: 201-204

Norberg J, Tedengren M (1995) Attack behavior and predatory success of Asterias rubens L. related to differences in size and morphology of the prey mussel Mytilus edulis L. J Exp Mar Biol Ecol 186:207-220

Oudejans RCHM, van der Sluis I, Voogt PA (1983) Triacylglycerol lipase activity in the storage organs of the sea star, Asterias rubens. Comp Biochem Physiol B 74:587-592

> Pansch C, Nasrolahi A, Appelhans YS, Wahl M (2012) Impacts of ocean warming and acidification on the larval development of the barnacle Amphibalanus improvisus. J Exp Mar Biol Ecol 420-421:48-55

Pansch C, Schraub I, Havenhand J, Wahl M (2014) Habitat traits and food availability determine the response of marine invertebrates to ocean acidification. Glob Chang Biol 20:765-777

> Parker LM, Ross PM, O'Connor WA, Borysko L, Raftos DA, Pörtner HO (2012) Adult exposure influences offspring response to ocean acidification in oysters. Glob Change Biol 18:82-92

> Pechenik JA (1999) On the advantages and disadvantages of larval stages in benthic marine invertebrate life cycles. Mar Ecol Prog Ser 177:269-297

> Peng RK, Williams DC (1973) Partial purification and some enzymatic properties of proteolytic enzyme fractions isolated from Pisaster ochraceus (echinoderm) pyloric caeca. Comp Biochem Physiol B 44:1207-1217

Pierrot D, Lewis E, Wallace DWR (2006) MS Excel program developed for $\mathrm{CO}_{2}$ system calculations. Macro for low salinities. Carbon Dioxide Information Analysis Center, Oak Ridge National Laboratory, US Department of Energy, Oak Ridge, TN

> Pineda MC, McQuaid CD, Turon X, Lopez-Legentil S, Ordonez V, Rius M (2012) Tough adults, frail babies: an analysis of stress sensitivity across early life-history stages of widely introduced marine invertebrates. PLoS ONE 7:e46672

Pörtner HO, Langenbuch M, Reipschläger A (2004) Biological impact of elevated ocean $\mathrm{CO}_{2}$ concentrations: lessons from animal physiology and earth history. J Oceanogr 60: $705-718$ 
Rochette R, Hamel JF, Himmelman JH (1994) Foraging strategy of the asteroid Leptasterias polaris: role of prey odors, current and feeding status. Mar Ecol Prog Ser 106: 93-100

Ross PM, Parker L, O'Connor WA, Bailey EA (2011) The impact of ocean acidification on reproduction, early development and settlement of marine organisms. Water 3:1005-1030

Roy RN, Roy LN, Vogel KM, Portermoore C and others (1993) The dissociation-constants of carbonic-acid in seawater at salinities 5 to 45 and temperatures 0 to $45^{\circ} \mathrm{C}$. Mar Chem 44:249-267

Saderne V, Fietzek P, Herman PMJ (2013) Extreme variations of $\mathrm{pCO}_{2}$ and $\mathrm{pH}$ in a macrophyte meadow of the Baltic Sea in summer: evidence of the effect of photosynthesis and local upwelling. PLoS ONE 8:e62689

Sanford E, Kelly MW (2011) Local adaptation in marine invertebrates. Ann Rev Mar Sci 3:509-535

Schram JB, McClintock JB, Angus RA, Lawrence JM (2011) Regenerative capacity and biochemical composition of the sea star Luidia clathrata (Say) (Echinodermata: Asteroidea) under conditions of near-future ocean acidification. J Exp Mar Biol Ecol 407:266-274

Siikavuopio SI, Mortensen A, Dale T, Foss A (2007) Effects of carbon dioxide exposure on feed intake and gonad growth in green sea urchin, Strongylocentrotus droebachiensis. Aquaculture 266:97-101

Sommer U, Meusel B, Stielau C (1999) An experimental analysis of the importance of body-size in the seastarmussel predator-prey relationship. Acta Oecol 20:81-86

Stumpp M, Wren J, Melzner F, Thorndyke MC, Dupont ST (2011) $\mathrm{CO}_{2}$ induced seawater acidification impacts sea urchin larval development. I. Elevated metabolic rates decrease scope for growth and induce developmental delay. Comp Biochem Physiol A Mol Integr Physiol 160: 331-340

Stumpp M, Trübenbach K, Brennecke D, Hu MY, Melzner F (2012) Resource allocation and extracellular acid-base status in the sea urchin Strongylocentrotus droebachiensis in response to $\mathrm{CO}_{2}$ induced seawater acidification. Aquat Toxicol 110-111:194-207

Stumpp M, Hu M, Casties I, Saborowski R, Bleich M, Melzner F, Dupont S (2013) Digestion in sea urchin larvae impaired under ocean acidification. Nature Clim Chang 3:1044-1049

Sunday JM, Crim RN, Harley CDG, Hart MW (2011) Quan-

Editorial responsibility: Peter Steinberg, Sydney, New South Wales, Australia tifying rates of evolutionary adaptation in response to ocean acidification. PLoS ONE 6:e22881

Thomsen J, Melzner F (2010) Moderate seawater acidification does not elicit long-term metabolic depression in the blue mussel Mytilus edulis. Mar Biol 157:2667-2676

Thomsen J, Gutowska M, Saphörster J, Heinemann A and others (2010) Calcifying invertebrates succeed in a naturally $\mathrm{CO}_{2}$-rich coastal habitat but are threatened by high levels of future acidification. Biogeosciences 7:3879-3891

> Thomsen J, Casties I, Pansch C, Körtzinger A, Melzner F (2013) Food availability outweighs ocean acidification effects in juvenile Mytilus edulis: laboratory and field experiments. Glob Chang Biol 19:1017-1027

Underwood AJ (1997) Experiments in ecology: their logical design and interpretation using statistical principles. Cambridge University Press, Cambridge

Vahl O (1984) The relationship between specific dynamic action (SDA) and growth in the common starfish, Asterias rubens L. Oecologia 61:122-125

> Vevers HG (1949) The biology of Asterias rubens L. Growth and reproduction. J Mar Biol Assoc UK 28: 165-187

> Wakefield RL, Murray SN (1998) Factors influencing food choice by the seaweed-eating marine snail Norrisia norrisi (Trochidae). Mar Biol 130:631-642

Waldbusser GG, Voigt EP, Bergschneider H, Green MA, Newell RIE (2011) Biocalcification in the eastern oyster (Crassostrea virginica) in relation to long-term trends in Chesapeake Bay pH. Estuaries Coasts 34:221-231

> Williams DC (1975) The occurrence and distribution of digestive enzymes in the pyloric caecum of the purple starfish Pisaster ochraceus. Comp Biochem Physiol A Comp Physiol 52:85-90

Wood HL, Spicer J, Widdicombe S (2008) Ocean acidification may increase calcification rates, but at a cost. Proc $\mathrm{R}$ Soc Lond B Biol Sci 275:1767-1773

> Wootton JT, Pfister CA, Forester JD (2008) Dynamic patterns and ecological impacts of declining ocean $\mathrm{pH}$ in a highresolution multi-year dataset. Proc Natl Acad Sci USA 105:18848-18853

> Yu PC, Matson PG, Martz TR, Hofmann GE (2011) The ocean acidification seascape and its relationship to the performance of calcifying marine invertebrates: laboratory experiments on the development of urchin larvae framed by environmentally-relevant $\mathrm{pCO}_{2} / \mathrm{pH}$. J Exp Mar Biol Ecol 400:288-295

Submitted: December 29, 2012; Accepted: May 27, 2014 Proofs received from author(s): July 31, 2014 